\title{
IMPLEMENTASI NILAI-NILAI PENDIDIKAN AGAMA ISLAM MULTIKULTURAL MELALUI EDU-EKOWISATA
}

(studi kasus Paguyuban Paku Lima Dusun Mandaran Desa Pesisir

Kecamatan Besuki Kabupaten Situbondo)

\author{
Masykuri Bakri \\ Universitas Islam Malang, Indonesia \\ masykuri@unisma.ac.id
}

Hambali

Universitas Islam Malang, Indonesia

hambali.amien@gmail.com

\author{
Agus Sulthoni Imami \\ Universitas Islam Malang, Indonesia \\ didienar@gmail.com
}

\begin{abstract}
Multicultural Islamic Education Paradigm is an Islamic teaching that emphasizes tolerance, harmony, moderation, and open dialogue in diversity. The reality of the pluralistic Indonesian nation requires a paradigm that can knit diversity. Multicultural Islamic Education is one means that can understand a diverse society about the importance of mutual understanding and cooperation in managing the sustainability of the coastal environment. In essence, beach tourism is also an instrument for scientific activities, beach tourism has an active role as an educational instrument and a playing media. This study aims to find the implementation of the values of Multicultural Islamic Religious Education through edu-ecotourism to support


religious education, mediation of horizontal social conflicts. The implementation of these values is a strategy for developing the community Paku Lima in Mandaran Hamlet, Pesisir Village, Besuki District, Situbondo Regency. The type of research used is qualitative research with a qualitative approach that is applied using in-depth interviews and group depth interviews. Determination of informants was done by purposive sampling, the number of respondents was 20 people from the association committee and 10 people from the surrounding community. Data were analyzed and analyzed using an interactive model using the theory of Miles, Huberman, and Saldana, namely: (1) data condensation, (2) presentation of data, and (3) drawing conclusions. Based on the results and data analysis, it was concluded that the implementation of PAIM values through edu-ecotourism was effectively applied through the community association, especially considering the complexity of problems arising from ethnic diversity and interests between groups. The strategy of developing the association by combining PAIM-oriented education with edu-ecotourism makes the association a vehicle for harmony and also as a mediator in resolving the problem of horizontal conflicts between ethnic communities

Keywords: Values Implementation, Multicultural Islamic, Edu-ecotourism, Paguyuban Paku Lima

\section{Pendahuluan}

Dinamika kehidupan masyarakat terbentuk sesuai dengan daerahnya masing-masing, tidak terkecuali dengan masyarakat pesisir. Wilayah pesisir merupakan daerah dengan masyarakat yang sangat majemuk dari segi budaya dengan karakteristik yang berbeda, tentunya keberagaman karakter atau ideologi juga mendasari keragaman kepentingan. Masyarakat pesisir memiliki suatu tatanan nilai, norma, dan kaidah-kaidah yang pastinya berbeda dengan budaya lainnya. Multikulturalitas di Indonesia merupakan realitas yang tidak mungkin dapat dipungkiri, begitu pula Masyarakat Pesisir dusun Mandaran yang terdiri dari beberapa golongan, apabila mampu mengaransemennya dalam sebuah keterpaduan akan menghasilkan keindahan dan kekuatan, tetapi juga bisa menjadi konflik sosial jika tidak terakomodasi dengan 
baik. Oleh karena itu, desain pembentukan dan dinamika kegiatan paguyuban disesuaikan dengan konsep pendidikan Islam moderat dan sesuai dengan desain mewujudkan cita-cita luhur menjadi bangsa yang sejahtera, perikemanusiaan yang beradab, berkeadilan sosial, dan demokratis. ${ }^{1}$

Kompleksitas lingkungan pesisir dan keberagaman budaya masyarakatnya menuntut pada pemahaman yang bersahabat dalam pengelolaannya. Karena sedemikian besarnya sumbangan lingkungan pesisir bagi masyarakat, namun dalam mengambil manfaatnya sejauh ini terkesan masih jauh dari nilai-nilai berkeadaban, kesejahteraan lingkungan seolah dikesampingkan, hal ini dikarenakan pemanfaatan manusia terhadap lingkungan tidak terarah, tidak diiringi rasa bertanggungjawab serta sangat membabi buta. Dari kasus inilah peran Pendidikan Agama Islam multikultural merupakan sarana yang dapat memahamkan masyarakat yang majemuk tentang pentingnya saling memahami dan bekerjasama dalam mengelola keberlangsungan lingkungan pesisir di berbagai lini.

Wisata pantai hakikatnya juga merupakan instrumen bagi kegiatan ilmu pengetahuan, wisata pantai memiliki peran aktif sebagai instrumen pendidikan maupun media bermain. Pantai mandaran Desa Pesisir Kecamatan Besuki Kabupaten Situbondo mempunyai wilayah tanjung yang potensial, yaitu daratan menjorok ke laut, daratan yang dikelilingi oleh laut di ketiga sisinya. Sebagian besar daratannya terdiri dari tumpukan pasir, potensi ini dibangun sebagai destinasi wisata pantai dengan beragam kegiatan positif, seperti pendidikan informal pada anakanak usia Sekolah Dasar, di samping upaya peningkatan pemahaman pendidikan keagamaan pada masyarakat melalui partisipasi ekologis, wisata ini juga berffungsi sebagai tempat edukasi mengimplementasikan nilai-nilai multikultural. Pengembangan potensi wisata bahari ini akan menarik semakin banyak wisatawan yang datang untuk berwisata. ${ }^{2}$

Asumsi awal yang dibangun adalah dibutuhkannya pengembangan media belajar untuk mengimplementasikan nilai-nilai

1 Abd Mu'id Aris Shofa,2016. Memaknai Kembali Multikulturalisme Indonesia dalam Bingkai Pancasila, Jurnal Pancasila dan Kewarganegaraan,1(1), h. 34-40.

2 Muflih, A. Fahrudin, dan Wardiatno. 2015. Kesesuaian dan Daya Dukung Wisata Pesisir Tanjung Pasir. Jurnal Ilmu Pertanian Indonesia 20(2): h. 141-149. 
melalui edu-ekowisata guna memberikan masyarakat pemahaman yang benar terhadap lingkungan. Implementasi nilai-nilai melalui eduekowisata hakikatnya adalah aplikasi pembelajaran yang disesuaikan dengan konsep wisata dan kecenderungan manusia secara umum, seperti: eksploring, bermain, dan tergalinya perasaan senang. Prinsip eduekowisata adalah menumbuhkan kesadaran lingkungan dan budaya, memberikan pengalaman positif pada wisatawan dan pemberdayaan masyarakat lokal. ${ }^{3}$

Analisa dalam tulisan ini berlandasakan pada norma dan nilai-nilai Pendidikan Agama Islam Multikultural (PAIM), signifikansi implementasi nilai PAIM ini terkait penentuan cara dan sarana untuk tujuan terbentuknya lembaga sosial berlandaskan nilai-nilai PAIM yang mengacu pada konsep menjauhkan diri dari kejahatan dan melaksanakan kebajikan. Penyajian nilai PAIM melalui edu-ekowisata diasumsikan tepat diberikan pada khalayak yang luas, tidak hanya terfokus pada suatu kalangan tertentu, karena wisata sebagai media pembelajaranya merupakan kebutuhan sekunder yang tidak terbatas dan semua ragam masyarakat bisa mengakses tanpa harus memperdulikan perbedaan budaya, bahkan perbedaan latar belakang wisatawan menjadi modal asimilasi nilai secara luas dan diasumsikan mampu mengubah opini diri menjadi lebih positif.

Mempertimbangkan alasan di atas, penelitian ini dilakukan dalam rangka menjawab pertanyaan bagaimana mengimplementasikan nilai-nilai PAIM melalui edu-ekowisata untuk mengembangkan paguyuban komunitas nelayan sehingga membentuk masyarakat yang moderat, dan selanjutnya mendukung ekonomi lokal Dusun Mandaran. Tujuan pengembangan komunitas ini adalah untuk menghasilkan media belajar inovatif dengan pemanfaatkan kawasan pesisir pantai guna mengharmonisasi dinamika kehidupan sosial masyarakat dan untuk mengatasi konflik nelayan yang sering terjadi di wilayah pesisir. Selanjutnya, tujuan penelitian adalah sebagai berikut: (1) memperoleh gambaran implementasi nilai-nilai pendidikan agama Islam multikultural, dan (3) untuk mendiskripsikan implementasi nilai-nilai Pendidikan 3 Nugroho, Iwan, 2015. Pengembangan Desa Melalui Ekowisata. Solo: Era Edicitra
Intermedia. 
Agama Islam multikultural melalui edu-ekowisata yang berorientasi pada pengelolaan keberlangsungan lingkungan pantai.

\section{Konsep pembelajaran edu-ekowisata Pantai}

Strategi pembelajaran dalam pengembangan edu-ekowisata yang bisa diterapkan yaitu merancang berbagai produk wisata dan mengembangkan kemampuan, keterampilan, dan kompetensi masyarakat sekitar. Edu-ekowisata adalah kemasan wisata yang memadukan konsep wisata dengan nilai-nilai pendidikan dan peningkatan pendapatan. Kemasan yang disajikan pun sangat sederhana tetapi memiliki bobot edukasi yang penting, seperti berwisata di desa-desa adat atau penjelasan mengenai pelestarian ekosistem laut. Pengembangan edu-ekowisata juga akan sejalan dengan proses pemberdayaan masyarakat. Dimana dengan dibukanya suatu daerah sebagai suatu kawasan edu-ekowisata secara otomatis masyarakat di dalamnya akan lebih diberdayakan dengan program pengembangan daerah wisata. Di sisi lain kearifan lokal masyarakat juga akan lebih terjaga, bahkan budaya masyarakat sebagai kearifan lokal menjadi aset pariwisata terbukti telah menyukseskan beberapa desa wisata. ${ }^{4}$

Edu-ekowisata laut adalah wisata alam yang mengandalkan keindahan pantai dan laut yang berbasis komunitas, dan melibatkan peningkatan pendapatan untuk kesejahteraan. Edu-ekowisata laut merupakan wisata edukatif, karena berorientasi pada keberlanjutan sumber daya alam. ${ }^{5}$ Masyarakat pesisir mulai banyak mengembangkan kegiatan ekowisata laut yang terintegrasi dalam kegiatan pendidikan. Tujuan integrasi ini adalah untuk meningkatkan pendapatan dan menjaga harmonisasi sosial kemasyarakatan. Masyarakat desa telah menjadi pelaku dengan terlibat dalam pengembangan lembaga dengan edu-ekowisata. Hal ini juga meningkatkan kesadaran masyarakat akan pelestarian alam. Pengelolaan ekowisata dapat dilihat di Desa Randutatah, Paiton, Probolinggo, ${ }^{6}$ dan di Desa Delegan, Kabupaten Gresik. ${ }^{7}$

\footnotetext{
${ }^{4}$ Suyanto, (2018). Model Kebijakan Pengelolaan Ekowisata Hutan Mangrove Berbasis Partisipasi Masyarakat Dan Potensi Lokal Kampung Laut Segara Anakan. Prosiding Seminar Nasional VIII (November): 8-16

5 Tuwo, A. (2011). Pengelolaan Ekowisata Pesisir dan Laut. Sidoarjo: Brilian Internasional, h. $28-29$

${ }^{6}$ Kartodiharjo H \& Jhamtani H (2006) Politik Lingkungan dan Kekuasaan di Indonesia.
} 
Prinsip-prinsip kegiatan edu-ekowisata dirancang berpusat pada peserta; mengembangkan kreativitas; menciptakan kondisi menyenangkan dan menantang; bermuatan nilai, etika, estetika, dan logika. Perhatian utama penelitian ini bertujuan menganalisa bagaimana penerapan pola edu-ekowisata dalam mengimplementasikan nilai-nilai multikultural dan tidak memusatkan pada standar kesejahteraan ekonomi. Konsep edu-ekowisata yang penulis kembangkan kemudian adalah lebih kepada desain objek wisata yang menyediakan pola pembelajaran dengan fasilitas lingkungan yang kemudian diturunkan sebagai segmen-segmen tema pembelajaran Pendidikan Agama Islam multikultural. Edu-ekowisata dalam tulisan ini mengurai kualitas pengalaman belajar dari beragam kegiatan yang dapat mengimplementasikan sikap multikultural yaitu mampu berkerjasama, terbentuknya solidaritas, tertanamnya rasa empati, toleransi beragama, dan kecakapan hidup membentuk afektif dan psikomotor yang moderat.

\section{Metode Penelitian}

Penelitian ini adalah penelitian kualitatif, pendekatan kualitatif diterapkan dengan menggunakan teknik in depth interview dan group depth interview, yaitu wawancara tentang bagaimana implementasi nilai-nilai pendidikan Agama Islam melalui edu-ekowisata di Paguyuban Paku Lima kecamatan Besuki, Situbondo. Review literatur sebagai penunjang dan pembeda dari peneliti lain yaitu tema edu-ekowisata dan implementasi nilai-nilai Pendidikan Agama Islam Multikultural. Metode in depth interview digunakan agar peneliti memperoleh informasi melalui wawancara secara individual melalui berbagai media untuk memperoleh pemahaman yang mendalam. Selanjutnya group depth interview merupakan teknik diskusi kelompok yang dikembangkan dari metode kelompok. Teknik ini digunakan dengan pertimbangan bahwa teknik ini dikembangkan melalui konsep bahwa proses berbagai masalah dan pengalaman individual mendorong individu untuk mengungkapkan lebih banyak pendapat dan pengalamannya. Peneliti juga menggunakan observasi partisipatif dan dokumentasi untuk sumber data yang sama.

Jakarta: Equinox Publishing Indonesia.h. 246-255

7 Kusnadi (2016) Membangun Desa Pesisir Menuju Kedaulatan Maritim Indonesia. Yogyakarta: Graha Ilmu. 
Teknik analisa data yang digunakan dalam penelitian ini adalah analisis kualitatif yakni analisis menggunakan model interaktif (interactive model analysis) yang terdiri atas tiga komponen analisis dengan menggunakan teori Miles, Huberman, dan Saldana, yakni : (1) Kondensasi data (pengembunan), (2) Penyajian data, dan (3) Penarikan kesimpulan (conclusion drawing) yang dilakukan secara berkesinambungan dalam dinamika edu-ekowisata di paguyuban Paku Lima. ${ }^{8}$ Selanjutnya analisis dilakukan dengan memadukan (secara interaktif) ketiga komponen tersebut, Data dikumpulkan secara langsung di lokasi penelitian melalui wawancara secara terstruktur (pedoman dengan kuisioner), dengan jumlah responden sebanyak 20 orang dari pengurus paguyuban dan 10 orang dari unsur masyarakat sekitar. Metode pengambilan sampel atau responden yang digunakan adalah purposive sampling, yaitu metode pengambilan sampel secara sengaja, berdasarkan pertimbangan tertentu.

\section{Hasil dan Pembahasan}

Paguyuban Paku Lima selain menjadi wadah berkumpul antar etnis masyarakat dan golongan, paguyuban ini juga menjadi representasi suatu komunitas multikultural yang mampu memediasi serta menyelesaikan masalah konflik horizontal etnis masyarakat. Lebih lanjut paguyuban ini diasumsikan menjadi wahana yang baik untuk mengimplementasikan nilai-nilai multikultural guna membentuk masyarakat moderat dan menjaga kelestarian lingkungan. Nilai multikultural pendidikan agama Islam yang dimaksud adalah pemahaman dan cara pandang interaksi sosial yang memperhatikan perbedaan golongan sebagai entitas dengan hak-hak yang setara. Dari nilai multikulturalisme inilah kemudian muncul gagasan normatif mengenai kerukunan, toleransi, saling menghargai perbedaan dan hak masing-masing individu. ${ }^{9}$

Paguyuban Paku Lima sebagai penguatan kelembagaan masyarakat pesisir di dusun Mandaran berkontribusi menjalankan empat fungsi multisektoral, antara lain; (1) Paguyuban sebagai wadah berkumpulnya masyarakat yang multietnis di Dusun Mandaran, yang terdiri dari etnis

\footnotetext{
${ }^{8}$ Saldana, J. (2011). Fundamentals of Qualitative Research: Understanding Qualitative Research. New York: Oxford University Press.

9 Achmad Fedyani Syaifuddin.2006. Membumikan Multikulturalisme Di Indonesia, Jurnal ETNOVISI, 2(1) h. 3-10.
} 
Madura dan etnis Mandar, (2) Paguyuban sebagai wadah pendidikan keagamaan Islam bagi masyarakat Mandaran yang rata-rata memiliki pengetahuan keagamaan Islam yang rendah, (3) Paguyuban sebagai konseptor dan pelaksana edu-ekowisata, dan (4) Paguyuban sebagai wadah yang dapat mengurangi konflik horizontal akibat perebutan lahan tanjung yang sudah lama tidak dimanfaatkan oleh warga sekitar.

Nilai inti dari Pendidikan Islam multikultural adalah humanistik, pluralistik, dan demokratis. Implementasi nilai yang ditanamkan melalui pendidikan islam multikultural adalah cara hidup saling menghormati, tulus, toleran terhadap keragaman, sehingga nilai tersebut dapat membentuk masyarakat yang menjunjung tinggi moralitas, kepedulian humanistik, kejujuran dalam berperilaku, dan bertanggungjawab. Asas nilai pendidikan agama Islam multikultural adalah membangun kehidupan bermasyarakat untuk memelihara saling pengertian (mutual understanding), sikap saling percaya (mutual trust), dan mengedepankan sikap saling menghargai (mutual respect), apresiatif, interdependensi, terbuka dalam berpikir, serta nir kekerasan.

Berdasar konsep tersebut, pengklasifikasian nilai-nilai pendidikan agama Islam multikultural perlu dilakukan, karena tidaklah semua nilai bisa dimasukan dalam kategori yang sama Ada sebagian nilai yang bersifat primer dan mendasar, sedangkan yang lainya bersifat sekunder dan tambahan. Beberapa nilai PAIM yang primer adalah rasa takut pada Allah, cinta kepada-Nya, berbuat baik pada semua makhluk, semangat kerjasama dengan sesama Manusia, berbuat adil dan jujur, toleran pada keberagaman, dan kasih sayang. Nilai-nilai PAIM yang mendasar tersebut adalah untuk mengantisipasi munculnya konflik yang diakibatkan ketidakmampuan menyesuaikan diri (maladjustmens). Sementara itu memahami nilai-nilai sekunder PAIM dapat dilihat sebagai landasan policy dalam corak kehidupan masyarakat yang beragam. Indikator nilai-nilai PAIM dalam kegiatan Paguyuban Paku Lima, khususnya sebagai organisasi kemasyarakatan dapat dirangkum dalam beberapa bentuk nilai multikultural, antara lain: 


\section{a. Nilai Inklusif dalam Kehidupan Sosial}

Sikap inklusif dalam kehidupan sosial tentunya juga tersirat nilai untuk saling menghormati dan tidak saling menganggu dalam perbedaan. Bagi Masyarakat pesisir yang multietnis nilai menjadi pondasi nilai yang terus disosialisasikan dalam kegiatan kemasyarakatan, karena dengan nilai ini organisasi kemasyarakatan dapat terbentuk dan bisa melaksanakan kegiatan kelembagaanya. Tentunya selain sebagai pondasi nilai kehidupan sosial dan terbentuknya organisasi kemasyarakatan, sikap inklusif atau terbuka dengan berbagai pihak --walaupun dengan orang yang tidak seiman-sangat tidak bertentangan dalam ajaran agama Islam, seperti halnya dijelaskan di dalam QS. Mumtahanah ayat 8-9:

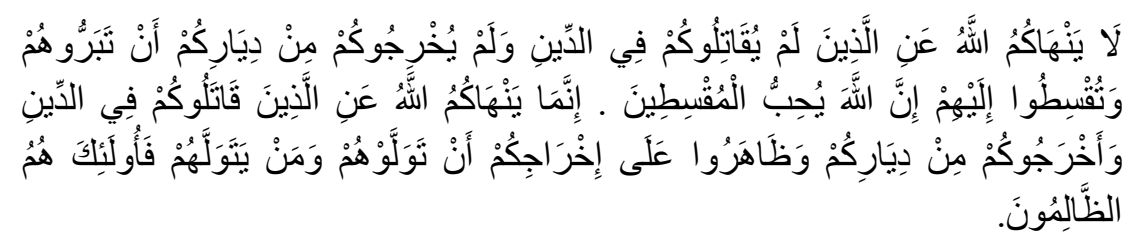

Artinya: "Allah tidak melarang kamu bergaul dengan orang kafir yang tidak memerangimu karena agama, dan mengusir kamu dari kampung halamanmu, sebaiknya Kamu berbuat baik dan berlaku adil kepada mereka, Sungguh Allah cinta pada orang-orang yang berlaku adil. Allah hanya melarang kamu berteman dengan orang-orang yang memerangimu karena agama, dan orang yang mengusir kamu dari tempat tinggalmu, serta membantu mereka yang mengusirmu untuk kamu jadikan kawan, siapapun yang menjadikan mereka sebagai kawan, merekalah betul-betul orang yang dzalim. ${ }^{10}$

Kaidah pertemanan atau bertetangga sebagai muslim dengan orang-orang yang tidak seiman ini menjadi latar belakang nilai pembentukan paguyuban masyarakat Dusun Mandaran sebagai sebuah wadah bagi masyarakat yang mulltietnis. Selain berdasar konsep nilai tersebut, dipandang perlu adanya keterlibatan pemerintah untuk memperkuat kelembagaan dalam sisi hukum, sehingga anggota paguyuban mendaftarkan komunitas ini kepada Kemenkumham yang

10 Dahlan, Zaini, 2020. Qur an Karim dan Terjemahan Artinya. Yogyakarta: UII Press, Cet. ke-20. h. 998-999 
akta pendirianya diterbitkan pada tanggal 31 Januari 2020 dengan nama "Masyarakat Peduli Lingkungan Paku Lima Mandaran".

\section{b. Pendidikan Islam Mederat (Tawassuth)}

Perubahan sosial di Dusun Mandaran sangat pesat akibat lokasinya yang strategis sebagai daerah eks-karisidenan, dan menjadi salah satu pusat ekonomi kota Situbondo, bahkan diprediksi akan berkembang dengan corak ragam budaya masyarakat. Sehingga tidak dapat dipungkiri bahwa beberapa konflik kemasyarakatan sering terjadi sebagai akibat dari ekspansi perkotaan dalam percepatan pembangunan. Konflik ini tentunya berimbas pada terbentuknya karakter masyarakat yang berorientasi pada kebahagiaan material, dibandingkan dengan kebahagiaan immaterial. Sebagaimana masyarakat bahari pada umumnya, khazanah Masyarakat pesisir tetap lebih menekankan pada kerukunan, kasih sayang, dan saling menghormati sebagaimana jargon moderasi pendidikan Islam. Muchlis M. Hanafi dalam Suharto (2015) memaknai moderat (al-wasat) sebagai metode berpikir, berinteraksi dan berperilaku secara seimbang dalam menyikapi dua keadaan, sehingga ditemukan sikap yang sesuai dengan prinsip-prinsip Islam dan tradisi masyarakat, yaitu seimbang dalam akidah, ibadah dan akhlak. ${ }^{11}$

Menurut KBBI offline versi 1.5, terma "moderat" memiliki dua makna, yaitu: (1) selalu menghindarkan perilaku atau pengungkapan yang ekstrem; dan (2) berkecenderungan ke arah dimensi atau jalan tengah. Oleh karena itu, paham moderat berarti paham yang tidak ekstrem, dalam arti selalu cenderung pada jalan tengah. Al-Qur'an menyebut umat Islam sebagai ummah wasatiyah sebagaimana QS. AlBaqarah: 143 yang artinya "Karena itu Kami jadikan kamu umat yang meniti jalan tengah, agar kamu manjadi saksi bagi orang banyak, dan rasul menjadi saksi bagimu", 12 yaitu umat "tengah-an", "moderat", adil, dan "terbaik"."

\footnotetext{
${ }^{11}$ Muchlis M. Hanafi.2013, Moderasi Islam: Menangkal Radikalisasi Berbasis Agama. Jakarta: Ikatan Alumni al-Azhar, h. 3-4

12 ibid. Dahlan, Zaini h. 38.

13 Toto Suharto, 2017. Penguatan Islam Moderat dalam Lembaga Pendidikan Islam di Indonesia; Al-Tahrir:17(1), h. 155.
} 
Selanjutnya merupakan sunnatullah dalam kehidupan sosial kemasyarakatan, Allah SWT menciptakan manusia dalam perbedaan dan keragaman. Al-Quran secara tegas dan gamblang menggambarkan keragaman tersebut dan agar kita saling bertoleransi, tolongmenolong, menghargai, dan saling memahami, serta sanggup menerima perbedaan dalam tatanan kehidupan sosial. Sebagaimana firman Allah SWT dalam QS. Al Hujarat ayat 13:

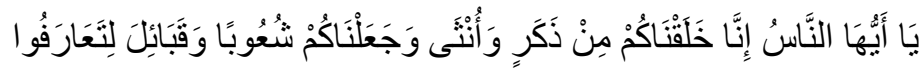

Artinya: "Hai manusia, sungguh Kami telah ciptakan kamu dari jenis laki-laki dan perempuan, dan Kami jadikan kamu berbangsa-bangsa dan bersuku-suku agar kamu saling mengenal dengan baik.". ${ }^{14}$ Kehidupan Masyarakat pesisir yang bersifat kolektif, ataupun paguyuban sebagai komunitas masyarakat tentu terdapat banyak keragaman atau perbedaan dalam berbagai hal. Walaupun demikian, perbedaan tersebut merupakan individu interdepedensi yang saling bergantung satu sama lainnya. Sehingga dengan perbedaan itu, Masyarakat dituntut agar saling mengenal dengan baik, saling berbagi, dan hidup rukun dalam perbedaan. Sehingga perbedaan menjadi berkah, dan bukan justru menjadi pembatas sebagaimana sering terjadi selama ini di beberapa daerah. ${ }^{15}$

Masdar Hilmy mengatakan bahwa konsep moderasi Pendidikan Agama Islam setidaknya meliputi beberapa karakteristik berikut: (1) Ideologi non-kekerasan dalam Islam, (2) Mengadopsi cara hidup modern dengan semua turunannya, termasuk sains dan teknologi, demokrasi, hak asasi manusia; (3) Penggunaan cara berpikir rasional; (4) Pendekatan kontekstual dalam memahami ajaran Agama Islam, dan; (5) Penggunaan ijtihäd (latihan intelektual) untuk membuat pendapat hukum Agama, jika tidak ada justifikasi eksplisit dari AlQur'an dan hadits. Selanjutnya menurut Hilmy karakteristik tersebut di atas dapat dikembangkan dalam bentuk yang lebih luas dalam

14 ibid. Dahlan, Zaini h. 931.

15 Waryono Abdul Gafur, 2005. Tafsir Sosial: Mendialogkan Teks dengan Konteks, Yogyakarta: eLSAQ Press. h. 11-12 
bingkai kehidupan, misalnya sikap toleran, harmonisasi, dan kerjasama di antara berbagai kelompok masyarakat dan Agama. ${ }^{16}$

\section{c. Nilai Toleran dalam bermasyarakat dan berorganisasi}

Pendidikan Agama Islam multikultural memandang bahwa kebijaksaan suatu kelompok juga menjadi nilai kebijaksanaan kelompok yang lain pula. Nilai toleransi dimanifestasikan dengan mengedepankan dialog sebagai muara kepekaan paguyuban terhadap kemungkinan permasalahan yang muncul. Pembelajaran yang mendukung paham multikultural banyak dikaji dalam beberapa analisa dinamika kemasyarakatan, tentunya dengan beberapa tema yang berbeda. Seperti halnya prinsip nilai dasar paguyuban Paku Lima yang mengharuskan kelapangan dalam semua kegiatan untuk menerima kultur yang luas guna mendapatkan pengetahuan yang komprehensif dan menyeluruh, yaitu tuntunan QS. Al-Mujaadilah ayat 11;

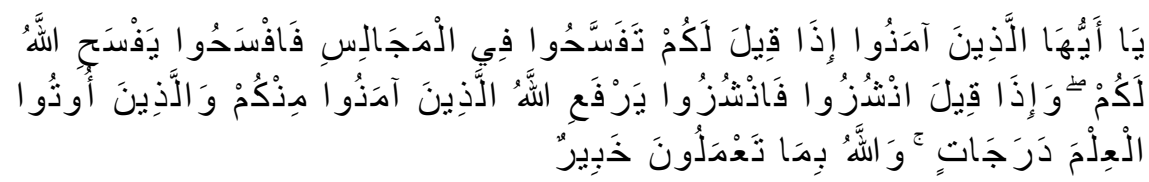

Artinya: Hai orang-orang beriman, bila diminta kepadamu: "berilah tempat di majelis," maka berilab keluasan kepadanya, niscaya Allah akan memberimu keluasan. Dan bila kamu diminta: "bangkitlab", maka bangkitlah dari tempat dudukmu. Allah pasti akan mengangkat orang-orang yang beriman dan berpengetabuan diantaramu beberapa tingkat lebih tinggi. Allab Maha Mengetahui segala yang kamu lakukan. ${ }^{17}$

Deskripsi QS. Al-Mujaadilah ayat 11 ini memberikan perintah pada individu untuk menjaga nilai toleran dan adab sopan santun dalam suatu majelis pertemuan dengan orang lain. Nilai toleran bukan sekedar dimaknai sebagai suatu sikap untuk dapat hidup bersama, namun juga nilai yang mengakui kebebasan individu untuk menjalankan prinsip hidup masing-masing, tanpa adanya paksaan dan tekanan. Hal demikian dalam tingkat praktik sosial masyarakat dapat

16 Masdar Hilmy, 2013. Whither Indonesia's Islamic Moderatism? A Reexamination on the Moderate Vision of Muhammadiyah and NU. Journal of Indonesian Islam, 7(1), h. 25-26.

${ }^{17}$ Ibid. Dahlan, Zaini (2020). h. 986-987. 
dilihat dari sikap kesadaran berorganisasi, karena toleransi yang paling hakiki adalah sikap kebersamaan, bertetangga dan bermasyarakat. Sehingga sikap toleran menjadi suatu keharusan pada komunitas masyarakat ataupun paguyuban, utamanya agar terbentuk sikap inklusif yang kemudian dapat menangkap ide pada tataran logika dan wacana, baik dengan kultur yang sama, ataupun orang yang berbeda kultur.

Fakta sejarah menggambarkan absennya sikap toleran yang terekam dalam al-Qur`an, diantara misalnya kisah kekejaman Ashabul Ukhdud (Yahudi Yaman) membangun parit api untuk membakar hidup-hidup kaum Nasrani Najran. Peristiwa yang begitu mencekam itu bermula dari ketidaksukaan para tokoh Yahudi atas banyaknya rakyat yang berubah haluan lebih memilih menjadi Nasrani. Begitu pula perseteruan mayoritas versus minoritas, sejarah mencatat banyak fakta di mana mayoritas cenderung ingin mendominasi di segala hal, menghalangi aktivitas minoritas, bahkan terkadang membabi buta merusak tempat ibadah agama minoritas. ${ }^{18}$

Konsep toleran adalah implementasi sikap menahan diri untuk tidak mengganggu dan tidak melecehkan individu yang memiliki kultur, agama, budaya, dan adat istiadat yang berbeda. Makna tasamuh yang sebenarnya bukanlah hanya persoalan akidah, tapi menghargai eksistensi orang lain, utamanya dalam dunia pendidikan. ${ }^{19}$ Pada tahap ini Paguyuban sebagai organisasi tranformasional memiliki peran untuk mengimplementasi nilai toleran dalam beberapa hal, yaitu; (1) Menstimulasi semangat para anggota dan kolega untuk melihat pekerjaan mereka dari beberapa perspektif baru, (2) Menurunkan visi dan misi kepada anggota dan kolega, (3) Mengembangkan kemampuan pada tingkat potensial yang lebih tinggi, dan (4) Memotivasi anggota dan kolega untuk mendorong ketercapaian kepentingan masing-masing, dan bermanfaat bagi organisasinya. ${ }^{20}$

\section{Implementasi Nilai-Nilai PAIM melalui edu-ekowisata}

Paguyuban Paku Lima sebagai wadah berkumpul dan sosialisasi nilai-nilai pada umumnya menjadi sarana tolong-menolong dan saling

\footnotetext{
${ }^{18}$ Shihab, M. Quraish, 1996. Wawasan Al-Qur'an Tafsir Maudhu'i. Bandung : Mizan. h. 57

${ }^{19}$ Baghowy. (2011). Tafsir: Maosoatul Quranil Adrim. Juz 8. Yaman. h. 77

${ }^{20}$ Bernard Bass. 2004. Kepemimpinan Transformasional. Stone op cit. h. 70
} 
bertukar informasi. Dimana melalui paguyuban sebagai representasi dari pilarisasi masyarakat, masing-masing elit yang memiliki kekuasaan dalam mengakses sumberdaya ekonomi saling menginformasikan dan saling membantu dengan tujuan peningkatan kesejahteraan. Pengembangan paguyuban melalui edu-ekowisata bergerak pada sektor kesenian, hiburan, pendidikan, dan ekonomi yang didasarkan pada nilai-nilai spiritual dan etika, estetika, dan psikologis, sehingga berbeda dengan destinasi wisata ansih yang kegiatanya lebih banyak dimotivasi pada kepentingan ekonomi saja.

Implementasi nilai-nilai PAIM melalui edu-ekowisata sebagai pengembangan Paguyuban Paku Lima berorientasi pada peningkatan kualitas SDM potensial melalui pelatihan keterampilan dan internalisasi pengetahuan pariwisata dengan berbagai mitra. Mereka juga menggunakan teknologi informasi berbasis Internet untuk mempromosikan dan mendukung pemasaran potensi wisata pantai pesisir. Sinergi pendidikan dan wisata yang dikemas dalam edu-ekowisata ini telah berkontribusi menciptakan ekonomi mandiri, kesejahteraan, dan mata pencaharian yang berkelanjutan bagi para masyarakat pesisir. Konsepsi pembangunan berbasis kemandirian lokal merekomendasikan pemanfaatan sumber daya alam dan karakteristiknya. ${ }^{21}$

Implementasi nilai-nilai PAIM melalui edu-ekowisata oleh Paguyuban Paku Lima dikembangkan dengan menyorot tiga aspek krusial, yaitu, Pertama, tujuan edu-ekowisata adalah untuk mencari titik temu antara praktik keagamaan dan ekonomi. Dalam konteks ini melalui edu-ekowisata, implementasi nilai-nilai Pendidikan Agama Islam multikultural bisa dipahami sebagai upaya mendorong masyarakat untuk saling berdialog guna pencapaian kesejahteraan sosial yang lebih baik. Kedua, implementasi nilai-nilai PAIM melalui edu-ekowisata bertujuan untuk menciptakan masyarakat multikultur yang rukun, harmonis, toleran, dan solider, hal ini penting dilakukan untuk mentransformasi pandangan keagamaan yang eksklusif menjadi lebih inklusif. Ketiga, implementasi nilai-nilai PAIM melalui edu-ekowisata dirancang untuk melawan kecurigaan masyarakat bahwa peran

\footnotetext{
21 Amien AM (2005). Kemandirian Lokal: Konsepsi Pembangunan, Organisasi, dan Pendidikan dari Perspektif Sains Baru. Jakarta: Gramedia. h. 171
} 
keagamaan menyimpan kepentingan tertentu yang merugikan, bahkan dianggap tidak bersentuhan dengan dinamika kehidupan masyakarat.

Sejak terbentuk pada pertengahan tahun 2018, Paguyuban Paku Lima telah mengadakan berbagai macam edu-ekowisata dengan beragam bentuk yang mengoptimalkan kawasan pantai dan beberapa destinasi sejarah karisedanan yang ada di lingkungan sekitar. Kemasan kegiatan sebagai implementasi nilai-nilai pendidikan Islam multikultural melalui edu-ekowisata yang dilakukan paguyuban Paku Lima, antara lain adalah sebaigai berikut:

\section{a. Implementasi Nilai-nilai PAIM Melalui Wisata Pantai}

Konsep implementasi nilai-nilai Islam multikultural melalui eduekowisata sebagai pengembangan kelembagaan Paguyuban Paku Lima adalah berupa desain pembelajaran dengan mejadikan lingkungan sebagai instrumen ruang pembelajaran yang enjoyment di alam terbuka tepi pantai. Konsep ini dilakukan dengan mengadakan wisata kopi pantai yang dibingkai dengan kegiatan musyawarah dan dialog interaktif yang dipandu oleh civitas akademika Universitas Nurul Jadid (UNUJA) mengulas tentang beberapa kajian untuk menyatukan perbedaan pandangan, kepentingan, etnis, dan kelompok untuk mencapai tujuan bersama yakni pemberdayaan sumber daya yang ada. Kegiatan wisata pantai ini merupakan suatu upaya merekonstruksi dari keanekaan budaya yang diarahkan kepada terbentuknya budaya lokal masyarakat Mandaran.

Kegiatan diskusi dalam wisata kopi pantai tersebut membahas tema diantaranya tentang dasar-dasar organisasi dan kepemimpinan, manajemen kegiatan guyub dan kerjasama antar anggota paguyuban dalam berbagai pelaksanaan kegiatan dengan pembagian tugas, semisal pembagian tupoksi bidang-bidang; bidang konsumsi, perlengkapan, akomodasi dan dokumentasi. Implementasi nilai-nilai di atas memanifestasikan kegiatan kerja bakti dalam bentuk partisipasi ekologis yang telah menjadi menjadi habit warga di dusun Mandaran, hal ini terlihat dalam kegiatan kerja bakti untuk membersihkan lingkungan, dan menanam tanaman pohon waru dan bakau, Gotong royong menimbun tangkis dengan pasir dalam karung, serta kerja bakti pembuatan, perawatan, dan perbaikan-perbaikan tangkis sungai. Budaya kerja bakti yang dilakukan setiap jum'at sore ini merupakan 
implementasi nilai-nilai pendidikan islam multikultural untuk saling bekerjasama dan terbuka menerima perbedaan masing-masing.

Implementasi nilai mutikultural dalam kegiatan ini adalah untuk mengintegrasikan metode transformasi dengan aktivitas nyata paguyuban di masyarakat, sehingga lebih lanjut pada gilirannya bisa berdampak terjadinya perubahan nilai sosial. Anggota paguyuban dan wisatawan tidak hanya dituntut untuk memahami dan membahas isuisu sosial, tapi juga melakukan sesuatu yang penting berkaitan dengan hal itu. Artinya, anggota paguyuban dan wisatawan tidak hanya berhenti pada penguasaan teori, tapi juga terjun langsung melakukan aksi-aksi nyata di masyarakat, sebagai usaha menerapkan teori-teori yang mereka peroleh dari ruang diskusi wisata pantai tersebut.

Implementasi nilai-nilai PAIM dengan model kegiatan ini akan lebih mudah diintegrasikan menjadi karakter individu, karena implementasi nilai multikultural dapat dipraktekan dalam realitas sosial, tidak hanya disajikan dengan menginformasikan ilmu pengetahuan, namun melalui konsep edu-ekowisata khususnya diskusi terbuka wisata pantai mengimplementasi nilai keterbukaan yang diupayakan agar peserta kegiatan mampu menyerap permasalahan yang timbul dalam kehidupan sosial dan memberikan alternatif pemecahanya. Sehingga sudah tentu implementasi nilai-nilai pendidikan Agama Islam multikultural harus disajikan secara terbuka, serta sukarela menghargai dan mengakomodir masing-masing perbedaan. Dengan kata lain, tidak sebuah kelompok masyarakat yang semena-mena terhadap kelompok lain dengan alasan apapun.

Selain wisata kopi pantai di atas, edu-ekowisata dikonsep dengan wisata mengelilingi taman mangrove untuk anak-anak wisatawan, di setiap tempat strategis di rute perjalanan pada saat mengelilingi hutan mangrove, wisatawan disajikan beberapa informasi pengajaran tentang ramah lingkungan. Dalam perjalanan mengelilingi taman, materi yang diberikan kepada peserta disajikan secara menarik melalui media langsung, seperti pohon mangrove, muara sungai, dan atmosfer, berikut juga dilengkapi dengan media permainan seperti papan cerita, puzzle, permainan karikatur, minicraf, papan petunjuk, dan papan identitas di beberapa item alam, dan lainya. 
Perjalanan Wisatawan juga disuguhi ajang silaturrohim antar umat beragama dengan mendatangi destinasi tempat budaya dan ibadah di sekitar pantai, seperti pelabuhan besuki, masjid agung besuki, Kelenteng Besuki, dan tempat-tempat bersejarah lainya. Selain perjalanan wisata mengelilingi tam mangrove dan tempat bersejarah tersbut, Paguyuban juga mengkampanyekan nilai-nilai multikultural dengan pamflet dan slogan dalam memandu perjalanan wisatawan dan di sekitar pantai. Hal ini dilakukan agar implementasi nilai-nilai islam multikultural bisa dijadikan sebagai pedoman hidup wisatawan. Kegiatan perjalanan wisata ini juga untuk memperkaya kurikulum dengan literatur dari atau tentang masyarakat yang berbeda kultur, etnis, atau agamanya. Implementasi nilai multikultural dengan kegiatan dengan mengajak wisatawan menilai atau menguji, dan kemudian mengapresiasikan cara pandang masyarakat, tentunya tanpa mengubah pemahamannya tentang hal itu, kegiatan ini dilaksanakan dengan melihat tata cara atau ritual ibadah, pernak-pernik dalam ritual ibadah, ornamen bangunan, dan ciri khas lainya.

\section{b. Implementasi Nilai-nilai PAIM Melalui Kegiatan Keagamaan}

Paguyuban Paku Lima mengimplementasikan nilai-nilai PAIM dengan mengadakan kegiatan keagamaan, kegiatan ini disediakan dalam format lesehan, surau atau musholla panggung kayu, ruang meeting atau kelas, dan di learning cofee, tempat pelaksanaan disesuaikan dengan kapasitas peserta. Pembuatan mushola Paguyuban dengan tanggung renteng, iuran antar anggota paguyuban serta pelibatan warga Mandaran untuk mewujudkan fasilitas dan sarana ibadah. Kegiatan keagamaan yang rutin dilakukan adalah kegiatan sholawatan yang dilaksanakan setiap 2 minggu sekali, tepatnya pada minggu kedua dan minggu ke 4 pada hari senin malam selasa. Melalui kegiatan keagamaan ini, upaya implementasi nilai-nilai moderasi keagamaan, khususnya adab sopan santun dalam majelis dengan orang lain sangat efektif diimplementasikan, apalagi pada kegiatan ini peleburan identitas individu tidak terlihat karena kegiatan tersebut didukung dengan ramah tamah antar peserta dengan makan bersama (tabheg) sebagai penutup acara kegiatan. 
Selain kegiatan tersebut Paguyuban juga melaksanakan kegiatan "Jum'at berkah", dimana anggota paguyuban dan kolega masyarakat sekitar pada setiap jum'at pagi dilaksanakan acara arisan, pembacaan tahlil, dan pembacaan sholawat nariyah. Kultum menjadi acara inti dalam kegiatan tersebut, Paguyuban mengundang tokoh agama untuk menyampaian materi tentang toleransi, tolong menolong, dan gotongroyong. karena kegiatan ini dimaksudkan sebagai upaya untuk mengikat anggota paguyuban dan masyarakat sekitar dalam bingkai persaudaraan dan saling kerjasama, tentunya dalam hal ini agar memiliki kesadaran tentang pentingnya rasa memiliki dan pelestarian lingkungan yang telah menyediakan beberapa potensi wisata bahari.

Kegiatan keagamaan lainya adalah Kajian al-Qur'an, al-hadits, dan kitab washiyatul Musthofa (membaca al-qur'an dan maknanya, membaca hadits dan maknanya) setiap Jum'at Pahing. Kegiatan ini diikuti oleh semua anggota paguyuban dan melibatkan masyarakat desa secara umum.

\section{c. Implementasi Nilai-nilai PAIM Melalui Kegiatan Seni Budaya}

Paguyuban Paku Lima juga mengimplementasikan nilai-nilai PAIM dengan mengadakan bulan lomba bagi masyarakat desa untuk memperingati hari kemerdekaan Republik Indonesia dan hari Besar lainya. Wisata dengan bingkai bulan lomba untuk menambah keakraban antar etnis masyarakat dan sikap bersaing secara fairplay tanpa menghilangkan budaya yang dianut, sajian perlombaan adalah perlombaan tradisional yang disesuaikan dengan potensi alam di sekitar pantai dusun Mandaran, seperti lomba layangan, permainan gubak sodor, voli pantai, dan lainya. Implementasi nilai toleransi kesalahan aturan main dan kesepakatan menjadi ajang hiburan disepakati oleh ketua kelompok peserta lomba sebelum dilangsungkanya perlombaan. Kegiatan ini adalah upaya mengatasi pendekatan kelompok secara spesifik, identifikasi, dan mengembangkan kemampuan untuk berkomunikasi secara crosscultural.

Sebagai prosesi kegiatan puncak bulan lomba, Paguyuban Paku Lima juga mengadakan wisata pentas seni lokal sesuai dengan etnis masing-masing. Kegiatan ini ditujukan agar Masyarakat mampu 
menghargai khazanah budaya yang dimiliki oleh etnis lainya. Bahkan sesuai usulan para anggota Paguyuban, pentas seni ini sebaiknya dilakukan setiap bulan ataupun setiap malam minggu di daerah pantai. Implementasi nilai estetik pada dasarnya mengajarkan masyarakat untuk berlaku sopan, santun, ramah, mencintai keindahan, dan mengutamakan kedamaian. Sebab segala materi jika hanya didekati secara doktrinal dan menekankan adanya otoritas-otoritas kebenaran, akan mengimplikasikan masyarakat cenderung bersikap kasar.

Dalam konteks ini Paguyuban memandang perlu pengembangan edu-ekowisata dengan pendekatan estetik untuk mengapresiasi segala gejala yang terjadi di masyarakat dengan melihatnya sebagai bagian dari dinamika kehidupan yang bernilai seni dan estetis. Kegiatan lomba dan pentas seni dilaksanakan dalam beberapa waktu tertentu sebagai ajang edu-ekowisata dalam rangka memperingati hari-hari besar nasional guna mengenali budaya masing-masing anggota dan menumbuhkan rasa toleransi terhadap perbedaan dengan membentuk kepanitiaan dalam mendukung kesadaran berorganisasi.

Paguyuban juga ikut andil melestarikan budaya tradisional pencak silat yang bekerjasama dengan Pagar Nusa MWC NU Besuki, kagiatan ini ditujukan sebagai ajang implementasi kerukunan antar kelompok, karena Paguyuban dalam lomba pencak silat ini mengundang utusan dari lembaga pendidikan formal tingkat SLTP dan SLTA, serta utusan lembaga informal seperti kelompok pencak silat klenteng besuki, dan pemangku kelompok masyarakat Mandar, Jawa, dan Madura di sekawedanan Besuki. Kegiatan ini bertujuan untuk memupuk sikap menerima, dan apresiasi terhadap kebudayaan kelompok yang berbeda dan pemahaman bahwa perbedaan budaya sebagai hal yang berharga dalam masyarakat. Di dalam kaitan ini, nilai pendidikan multikultural diarahkan kepada memperkuat keadilan sosial dengan menentang berbagai jenis diskriminasi.

Berbeda dengan kegiatan ajang lomba tradisional dan pentas seni, Paguyuban juga mengimplementasikan nilai keakraban dan kerukunan antar anggota dan masyarakat sekitar dengan mengadakan kegiatan senam bagi ibu-ibu nelayan pada setiap kamis 
sore di sekitar pantai. Kegiatan senam bersama ini bisa diakses secara umum dan dipandu oleh instruktur senam profesional, karena konsep edu-ekowisata yang ditawarkan adalah menyatukan antara kebugaran, keakraban, dan keindahan panorama pantai saat senja, tak pelak kegiatan ini lebih bisa menarik antusias beberapa wisatawan dari berbagai daerah sekitar desa pesisir. Pendekatan ini mencoba memberikan penyadaran kepada masyarakat untuk tidak membedakan jenis kelamin antara laki-laki dan perempuan. Sebab sebenarnya jenis kelamin bukanlah hal yang menghalangi seseorang untuk mencapai kesuksesan, melainkan kerja nyata yang dilakukannya. Dengan kegiatan forum ibu ini, segala bentuk konstruksi sosial dapat menghilangkan isu gender dalam masyarakat.

\section{Kesimpulan}

Impelementasi nilai pendidikan islam multikultural melalui eduekowisata di Pantai Mandaran telah menciptakan warna baru, usaha yang dilakukan secara sadar dan terencana untuk mengaktualisasikan kesadaran akan nilai-nilai multikultural dalam kehidupan sehari-hari siswa melalui pengembangan kompetensi pengetahuan, sikap spiritual, sikap sosial, dan keterampilan. Dalam konteks edu-ekowisata, Anggota paguyuban sebagai grand designer memiliki peranan untuk menciptakan suasana wisata dengan fasilitas pembelajaran yang interaktif, inspiratif, inovatif, dan menyenangkan.

Edu-ekowisata pada dasarnya berperan mewujudkan proses pembelajaran (learning process) dan hasil belajar (learning values) dalam menanamkan nilai-nilai ajaran islam yang bersumber pada spirit ajaran islam yaitu dengan berpedoman kepada Al-quran dan al-Hadits meliputi aqidah, ibadah, mu'amalah, akhlak, dan sejarah kebudayaan islam. Oleh karena itu, strategi perbaikan dalam konteks pengembangan edu-ekowisata dapat berkontribusi meningkatkan kesadaran multikultural keagamaan dengan pendekatan inovatif guna mengatasi masalah horizontal kemasyarakatan.

Nilai-nilai multikulturalisme yang diimplementasikan kepada wisatawan dan Masyarakat sekitar adalah pengembangan kompetensi sikap sosial diantaranya adalah; (1) nilai inklusif (terbuka); (2) nilai mendahulukan dialog; (3) nilai kemanusiaan (humanis); (4) nilai toleransi; (5) nilai tolong menolong (gotong royong); dan (6) nilai keadilan 
(demokratis). Pada praktiknya pelaksanaan implementasi nilai pendidikan Islam multikultural tidak perlu membentuk sebuah kurikulum, namun diimplementasikan dengan memanfaatkan lingkungan dan sumber daya yang ada.

Anggota paguyuban memegang peran kunci dalam mengimplementasikan nilai-nilai Pendidikan Agama Islam multikultural dengan konsep edu-ekowisata, pelibatan penuh setiap elemen masyarakat diperlukan dalam rangka mengembangkan dan mengelola destinasi wisata. Di Desa Pesisir masih diperlukan pengembangan kapasitas komunitas paguyuban untuk mengelola konsep edu-ekowisata dengan lebih maksimal. Menurut penjelasan Ketua Paguyuban Komunitas Nelayan Desa Pesisir bahwa, Paguyuban telah beberapa kali mengikuti pelatihan yang terkait pengelolaan wisata baik dalam hal manajemen wisata. Pelatihan ini ada yang diinisiasi oleh pemerintah dan pelatihan yang diselenggarakan oleh Universitas Nurul Jadid (UNUJA) sebagai kegiatan pengabdian kepada masyarakat. Namun walaupun demikian tetap diperlukan upaya berkelanjutan dalam peningkatan kapasitas Paguyuban yang dituangkan dalam strategi pengembangan edu-ekowisata Dusun Mandaran.

Upaya implementasi nilai pendidikan islam multikultural ini dilakukan dengan mengasimilasi dan memadukan nilai-nilai pendidikan islam multikultural dengan kegiatan wisata pantai, seminar, silaturrohim dalam bingkai lomba dan pentas seni, dan pelatihan koperatif antar etnis masyarakat dengan mengundang tenaga ahli profesional. Kegiatan implementasi nilai-nilai pendidikan islam multikultural melalui eduekowisata ini tidak hanya akan mengubah pengetahuan atau pemahaman masyarakat, tetapi juga membantu mengembangkan keterampilan teknis yang dibutuhkan untuk mendukung pengelolaan ekowisata laut yang berkelanjutan. Dengan demikian, penduduk setempat memiliki kemampuan dan keterampilan kreatif untuk mengembangkan layanan pariwisata dengan produk pariwisata yang berkualitas dan produk pembelajaran pendidikan Islam multikultural yang menawarkan kerukunan antar etnis, gotong royong, dan keharmonisan. 


\section{Daftar Pustaka}

Abd Mu`id Aris Shofa, (2016), Memaknai Kembali Multikulturalisme Indonesia dalam Bingkai Pancasila; Jurnal Pancasila dan Kewarganegaraan, 1 (1)

Achmad Fedyani Syaifuddin, (2006), Membumikan Multikulturalisme di Indonesia, Jurnal Antropologi sosial budaya, Etnovisi, 2 (1)

Amien AM (2005) Kemandirian Lokal: Konsepsi Pembangunan, Organisasi, dan Pendidikan dari Perspektif Sains Baru. Jakarta: Gramedia.

Dahlan, Zaini, 2020. Qur an Karim dan Terjemahan Artinya. Yogyakarta: UII Press, Cet. 20.

H.A.R Tilaar (2004), Manajemen Pendidikan Nasional, Bandung: PT. Remaja Rosdakarya

Kartodiharjo H \& Jhamtani H (2006) Politik Lingkungan dan Kekuasaan di Indonesia. Jakarta: Equinox Publishing Indonesia.

Kusnadi (1998) Jaringan Sosial sebagai Strategi Adaptasi Masyarakat Nelayan: Studi Kasus di Desa Pesisir, Kecamatan Besuki, Kabupaten Situbondo, Jawa Timur. Tesis, Program Studi Antropologi, Program Pascasarjana, Universitas Indonesia, Jakarta.

Kusnadi (2006) Konflik Sosial Nelayan: Kemiskinan dan Perebutan Sumberdaya Perikanan. Yogyakarta: LKiS.

Kusnadi (2016). Membangun Desa Pesisir Menuju Kedaulatan Maritim Indonesia. Yogyakarta: Graha Ilmu.

Kusnadi \& Sumarijono (2016) Paradoks Revolusi Biru: Perspektif Teori Involusi Clifford Geertr: Jember: Laporan Penelitian Fundamental DP2M, Universitas Jember.

Little D (1991) Varieties of Social Explanation: An Introduction to the Philosophy of Social Science. Oxford: Westview Press.

Mubyarto, Soetrisno L, \& Dove M (1984) Nelayan dan Kemiskinan: Studi Ekonomi Antropologi di Dua Desa Pantai. Jakarta: Rajawali Pers.

Muchlis M. Hanafi, (2013), Moderasi Islam: Menangkal Radikalisasi Berbasis Agama, Jakarta: Pusat Studi Al-Qur'an

Muflih, A. Fahrudin dan Y. Wardiatno. (2015). Kesesuaian dan Daya Dukung Wisata Pesisir Tanjung Pasir. Jurnal Ilmu Pertanian Indonesia 20(2):141-149.

Mundzier Suparta (2008), Islamic Multicultural Education: Sebuah Refleksi atas Pendidikan Agama Islam di Indonesia, Jakarta: Ghazali Center.

Muqtafa MK \& Nadila SM (2011) Climate change dan dampaknya terhadap komunitas nelayan dan masyarakat hutan. Jurnal 
Masyarakat dan Budaya, 13

Nugroho, Iwan (2015), Pengembangan Desa Melalui Ekowisata. Solo:

Edicitra Intermedia

Perry RI (2010) Potential impacts of climate change on marine wild capture fisheries: An update. Journal of Agricultural Science, 149

Saldana, J. (2011). Fundamentals of Qualitative Research: Understanding Qualitative Research. New York: Oxford University Press.

Shihab, M.Quraish (1998). Wawasan Al-Quran: Tafsir Maudhu'i atas Pelbagai Persoalan Umat, Bandung: Mizan.

Tuwo A (2011) Pengelolaan Ekowisata Pesisir dan Laut: Pendekatan Sosialekonomi, Kelembagaan, dan Sarana Wilayah. Sidoarjo: Brilian Internasional.

Toto Suharto (2017), Indonesiasi Islam; Penguatan Islam Moderat dalam Lembaga Pendidikan Islam Di Indonesia, Al-Tahrir; Jurnal Pemikiran Islam

Waryono Abdul Gafur (2005), Tafsir Sosial: Mendialogkan Teks dengan Konteks, Yogyakarta: eLSAQ Press 
Masykuri Bakri, Hambali \& Agus Sulthoni Imami 